\title{
Development of Natural Dyeing Color Decorations on Traditional Nias Pandanus Weaving as a Souvenir Product
}

\author{
Kezia Clarissa Langi ${ }^{1, *}$, Dian Widiawati ${ }^{2}$, Setiawan Sabana ${ }^{3}$ \\ ${ }^{1}$ Bandung Institute of Technology \\ ${ }^{2}$ Bandung Institute of Technology \\ ${ }^{3}$ Bandung Institute of Technology \\ *Corresponding author.Email kezialangi91@student.itb.ac.id
}

\begin{abstract}
One of the cultural treasures in Nias is the tradition of weaving made from pandan thorn leaves (Pandanus tectorius) called sinasa leaves or swamp grass (Eleocharis dulcis) called keleömö. Various weaving patterns with very distinctive structures can be found in this area comparing to those of other regions. Some of the compositions are made with a certain color composition. Unfortunately, the knowledge of traditional weaving dyeing techniques in Nias has extinct. Traditionally, the people of Nias use the fruit of the Sianuza tree to produce red, the forest banana tree trunk for purple, and turmeric for yellow. The loss of traditional knowledge in extracting colors and the long process of making natural dyes made Nias people turn to synthetic dyes to color their traditional weaving. This research aims to revitalize Nias natural dyeing practice by exploring Nias biodiversity and adapt the exploration into souvenir products. Through an understanding of natural dyeing techniques that have been carried out in Indonesia and the research material that Nias has, a natural dyeing can be an added value and become an appeal for souvenir products in the area. This is also in line with the concept of sustainability which is currently being echoed globally. The research method was carried out with quantitative methods through experimentation. The data collection stage was done by collecting references around Indonesian natural dyes that could be adapted for Nias such as gambier (Uncaria gambir Roxb), turmeric (Curcuma domestica), and betel nut (Areca catechu L.) with hydrated lime $\left(\mathrm{Ca}(\mathrm{OH})_{2}\right)$ and vinegar $\left(\mathrm{CH}_{3} \mathrm{COOH}\right)$ as the color amplifier. The exploration stage for natural dyes is carried out by manually introducing efficient natural dye materials and techniques. The results of this research are three explorations of natural dyes as a reference for the development of traditional Nias souvenir products.
\end{abstract}

Keywords: Craft industry, natural dyeing, Nias, traditional weaving

\section{INTRODUCTION}

This paper presents initial findings from an ongoing research project that explores possibilities for Nias natural dyeing techniques based on an understanding of natural dyeing techniques that have been carried out in Indonesia.

Nias is an island on the outer zone of Indonesia, located on the West side of Sumatra Island. Nias has been the host of several international events, such as World Surf League (WSL) in 2018 and Sail Nias in 2019. Nias nature and tradition has been a tourism that attracts domestic and international visitors. The number of tourists entering Nias increasing each year. According to the South Nias Regency Statistics Center, in during 2013, 2014, and 2015, there are $2.360,4.256$, and 4256 international tourists; and 23.684, 24.873, and 24.873 domestic tourists visiting Nias through Gunungsitoli city [1]. Gunungsitoli City is the oldest and largest city the province of North Sumatra, Indonesia, which is located on the island of Nias. Gunungsitoli is also the city where the Binaka Airport, Nias Heritage Museum, and Nias Heritage and Empowerment Foundation is located. One of the significant part of traveling experience is souvenir [2]. Tourists spend as many as third of a traveler's budget [3]. Souvenir purchases allow travelers to turn 
intangible encounters they have during their stay into physical memories. Moreover, souvenir has a symbolic value and sustain the tourism development as well as the cultural and traditional craft [4].

The number of tourists visiting Nias gives a promising souvenir industry potential. Tourists define authenticity of a local souvenir with the category of: a craft's uniqueness, workmanship, aesthetics and use, cultural and historical integrity, and genuineness [5]. Nias produce handicraft items sold as souvenirs, one of them are woven crafts such as traditional mats and pouches. It is unknown when exactly the weaving technique was created, but through folklore about the origin of the Nias people (ono Niha), it shows that their ancestor, were descended from the sky with all knowledge and expertise in various fields of life, including weaving and container making [6]. Therefore, traditional weaving is a cultural heritage that is closely related to their daily lives.

Natural dyeing techniques in Nias are no longer used. The loss of documentation and the decline of ancestral natural dyeing skills have resulted in the current Nias people being unfamiliar with natural dyeing techniques. Now, dyeing is done with synthetic dyes that are easily available but have a negative impact on the environment. The longing of the people and observers of Nias culture is to revive the natural dyeing technique as practiced by their ancestors [7].

For centuries Indonesia has use natural dyes for its textile and craft products. The unique aspect of Indonesian natural dyes is the spiritual meaning embedded in the colors for sacred cloth. Natural dyes extracted in Indonesia are quite similar. This happens because mainly the dyes are produced from wood, barks, leaves, and roots of plants or trees from the surroundings of the producers [8]. Studies involving Indonesian natural dyes has been done and can be adapted into Nias traditional weaving. The selection of native Nias vegetation as a natural dye can make its use feasible and enhance Nias biodiversity.

Natural dyes are believed to favor the development of sustainable products and has less impact to the environment and health. Compared to synthetic dyes, it is less allergenic and toxic to the human body [9]. Moreover, the water waste can be treated by biodegradation. Foreign tourist tends to purchase products with natural dyes. In addition, based on the Revision of the European Ecolabel and Green Public Procurement (GPP) Criteria for Textile Products since November 2013 the European Union has banned the use of some azo dyes which are usually used as synthetic dyes for textiles due to their carcinogenic impact on the environment [10]. The lengthy process of natural dyeing takes time; therefore, the price is more expensive.

Research on natural dyes in recent years has been increasing, contributing to the recovery of traditional knowledge. Research of natural dye plants used by Dayak Iban in Sungai Utik, West Kalimantan, was conducted by Wahdina, Setiadi, Purwanto and Qayim [11]. The research identified 15 plant species used as dye plants in Sungai Utik Village. The dye plants produced white, red, and black colors. The most important dye plants are engkerebai kayoh (Psychotria malayana) that produces red and rengat kikat (Clerodendrum laevifolium) that produces black. Natural dyeing is commonly used for plaiting and weaving.

Natural dyeing techniques should be a skill and knowledge that is passed on to the younger generation to preserve tradition and protect nature. However, with modernity, Nias natural dyeing has extinct. The synthetic dyeing which is harmful for the body and environment makes woven products less desirable. Traditional Nias weaving products need to be developed visually, by design, and by necessity. This fact provides an opportunity for this research with the benefit of being a souvenir or typical Nias souvenir made by the Nias Small and Medium Industry.

\section{MATERIAL AND METHOD}

\subsection{Method}

The research method was carried out with quantitative methods through experimentation. Through quantitative methods, researchers intend to understand in depth a complex and meaningful social situation. The method used in the experimental approach is to make several examples manually through the natural dyeing experiments. These experiments are expected to be applied on Nias woven souvenirs.

\subsection{Data Collecting}

Due to the Covid-19 pandemic, information about the traditional weaving and its dyeing process was obtained through an online in-depth interview technique from May until June with the chairman of Nias Heritage and Empowerment Foundation, Dina Waoma, who regulate the activities of the foundation. The foundation is a social and non-profit organization focusing on the preservation of Nias culture. The questions were asked about the traditional weaving, kind of dye plants used in the past, current synthetic 
dye, and discussion of potential dye plants material that are native in Nias.

\subsection{Procedure}

Nias woven material, the sinasa leaves in raw and woven form are sent to Bandung for natural dyeing explorations. Natural dyeing material used in this research are gambier (Uncaria gambir Roxb), turmeric (Curcuma domestica), and betel nut (Areca catech $L$.) with hydrated lime $\left(\mathrm{Ca}(\mathrm{OH})_{2}\right)$ and vinegar $\left(\mathrm{CH}_{3} \mathrm{COOH}\right)$ as the color amplifier. Gambier and hydrated lime are used in afo, a concoction of five Nias ritual ingredients used for welcoming guests; along with turmeric and vinegar that are used in daily Nias household. The results of these experiments are documented and will be taught online to the Nias Heritage and Empowerment Foundation.

\subsection{Data analysis}

Data from in-dept interview and natural dye experiment were descriptively analyzed and presented in tabulation form. The color produced from the dye plant was characterized using the Pantone Color Chart in daylight to obtain a standard color. The color codes were provided using the Pantone Color Chart through an online download.

\section{RESULT AND DISCUSSION}

There are three types of weaving in Nias, Nila'elae, which is plain weaving, Nisora, that is weaving with the combination of several motifs with colors, and Ni'otarawa, the see-through weaving. The weaving of Ni'otarawa is traditionally not dyed but using a colored fabric as its background. Therefore, this paper develops natural dyeing color decorations on Nisora weaving.

Traditional Nias weaving are made from pandan thorns leaves (Pandanus tectorius) called sinasa leaves or swamp grass (Eleocharis dulcis) called keleömö [12]. This paper uses sinasa leaves for the coloring and weaving material. The leaves were cleaned from its thorns, dried, and flattened (see Figure 1a) then colored and woven (Figure 1b, 1c). Natural dyeing in Nias has extinct since the presence of synthetic dyeing. Today, Nias elder can perform the traditional weaving, however lost the knowledge of natural dyeing [7].

Bolanafo is formed from the word 'bola' and 'afo'. In Nias language, 'bola' means 'place' and 'afo' referring to the five traditional ingredients of tawuo or betel leaf, betua or hydrated lime, gambe or gambier leaf, bago or tobacco, and fino or betel nut (fino) [7], [13]. Bolanafo literary means 'a place to store betel'. Bolanafo presented at traditional welcoming ceremonies or weddings to show respect to the guest. Presenting afo in Bolanafo shows a piety attitude [14].

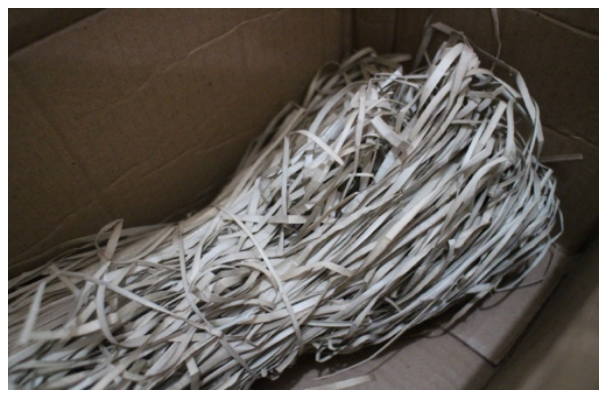

(a)

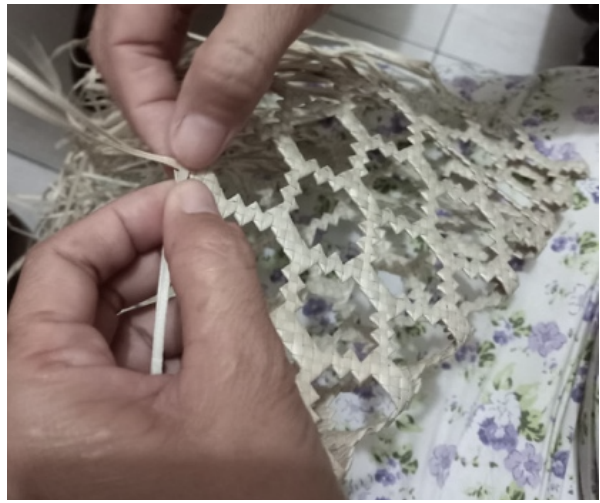

(b)

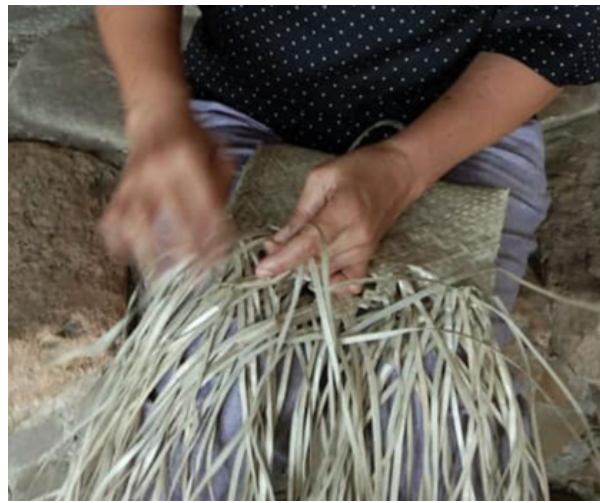

(c)

Figure 1 (a) Raw Sinasa material ready to be colored or weaved; (b) see-through weaving process; (c) plain weaving process 


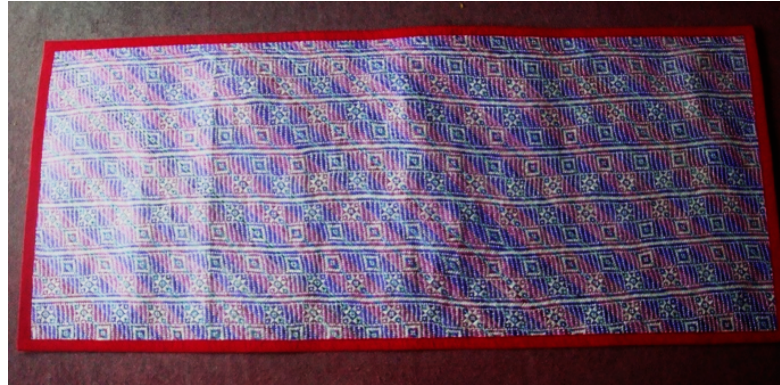

(a)

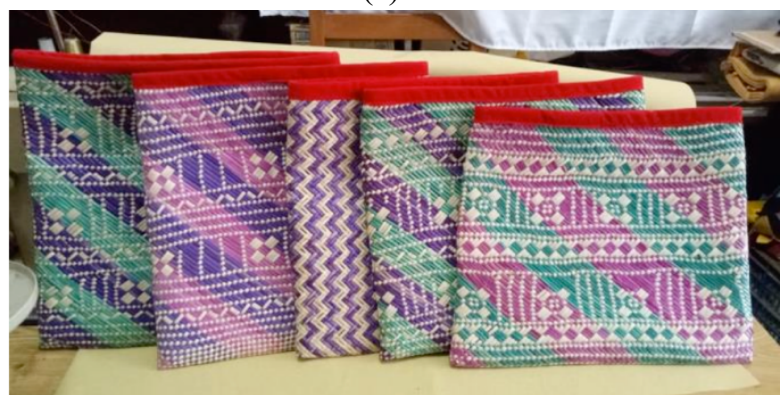

(b)

Figure 2 Traditional Nias weave with synthetic coloring in the form of (a) mat and (b) bolanafo.

\subsection{MORDANTING}

Mordanting is a fixative that allows dye molecules to bind into fiber ensuring that textiles are colorfast; occasionally at the same time giving a discoloration effect. Mordant is taken from the old French word mordre or "to bite" [15]. With a certain method, mordanting will produce a diverse color variant, even though it only uses one natural dyeing source. This research uses these type of mordants: hydrated lime $\left(\mathrm{Ca}(\mathrm{OH})_{2}\right)$ and vinegar $\left(\mathrm{CH}_{3} \mathrm{COOH}\right)$. The use of mordant can cause color changes, therefore, it can be used in the exploration process to produce a variety of attractive colors (see Table 1).

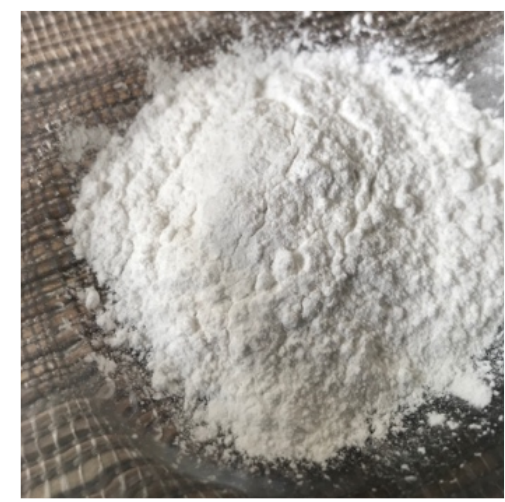

(a)

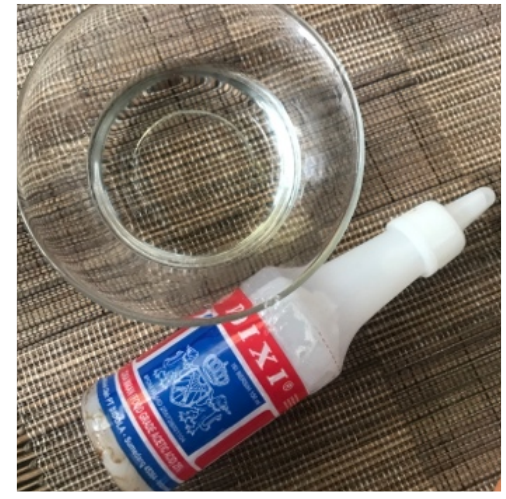

(b)

Figure 3 Types of mordant used in this paper: (a) hydrated lime $\left(\mathrm{Ca}(\mathrm{OH})_{2}\right)$ and vinegar $\left(\mathrm{CH}_{3} \mathrm{COOH}\right)$.

\subsection{Natural Dyeing Experimentation}

Based on the results of interview, literature review, and exploration, the natural dyeing extraction used in this research can be seen in Table 1 .

The first natural dyeing used in this paper is gambier. The world's exporter of gambier extract came from the West Sumatra. Gambier (Uncaria gambir Roxb) has been commonly used as a natural dye for batik in Indonesia [16]. The following are some of the steps taken in the gambier experimentation: first, boil $2 \mathrm{~L}$ water in a tub on medium heat. Second, weighing the gambier extract with a digital scale into $20 \mathrm{~g}$. Third, after the water in the tube boils, insert the Gambier extract and mix thoroughly. Fourth, wet the sinasa leaves using water first before dipping it into the dye. Fifth, inserting the sinasa leaves within 25 minutes. Sixth, lift and dry the sinasa leaves in the sun. After this process, the fibers are washed and immersed into $10 \mathrm{~g}$ hydrated lime $\left(\mathrm{Ca}(\mathrm{OH})_{2}\right)$. In result, the color appears to be brown or PANTONE 17-1112 TCX in Weathered Teak. This experiment concludes that Gambier is not an effective natural dyeing for sinasa leaves because the dye did not penetrate the fibers fully. The end results appear to be brown-green similar with the original sinasa color.

Second natural dyeing is turmeric. Turmeric is a natural dye that is widely used as a natural dye because of its expertise in producing range of yellow color. To extract turmeric into dye, first the turmeric is peeled and washed to remove dirt. The turmeric is then cut and mashed until smooth and boiled in a 1:4 ratio of water. To achieve the best dyeing results, simultaneous extraction and dyeing is done. The dyeing of substrate is carried out in same water bath along with extraction of dye from the raw material. 
Less temperature and reduced time of dyeing are proven to give better results in terms of color appeal [17]. After 15 minutes, the sinasa leaves are lift and dried in the sun. When the leaves are dried, it is washed and immersed into the hydrated lime $\left(\mathrm{Ca}(\mathrm{OH})_{2}\right)$ and vinegar $\left(\mathrm{CH}_{3} \mathrm{COOH}\right)$. This paper uses $10 \mathrm{~g}$ of hydrated lime and $10 \mathrm{ml}$ of vinegar. Sinasa leaves in hydrated lime mordant appears to be yellowbrown or PANTONE 16-0946 TCX in Honey and vinegar mordant appears to be yellow-green or PANTONE 17-0636 TCX in Green Moss.

Third natural dyeing is betel nut (seed of the fruit of the areca palm). Betel nuts are found and used in traditional Nias rituals, however, are not used in natural dyeing. Betel nut (Areca catechu L.) is commonly used for consumption, cosmetics, health, and dyes in the textile industry [18]. To extract the color, betel nuts are first sliced and dried. This paper uses $20 \mathrm{~g}$ of dried betel nuts and boiled in $4 \mathrm{~L}$ of water. After the extraction, the betel nuts are removed. The sinasa leaves are damped with water first before immersing it into the dye within 30 minutes. Afterwards, the fibers are dried in the sun. After this process, the dyed sinasa leaves are washed and immersed into $10 \mathrm{~g}$ of hydrated lime $\left(\mathrm{Ca}(\mathrm{OH})_{2}\right)$. Sinasa leaves in hydrated lime mordant appears to be burgundy or PANTONE 19-1625 TCX in Decadent Chocolate.

Table 1 Exploration of plant species used as natural coloring agents for Nias Pandanus Weaving

\begin{tabular}{|c|c|c|c|c|}
\hline \multirow[b]{2}{*}{ No } & \multirow{2}{*}{$\begin{array}{c}\text { Local / Indonesian / } \\
\text { English / Scientific } \\
\text { name/Plant part }\end{array}$} & \multirow[b]{2}{*}{ Processing method } & \multicolumn{2}{|c|}{ Color produced } \\
\hline & & & $\begin{array}{l}\text { Hydrated lime } \\
\qquad \mathrm{Ca}(\mathrm{OH})_{2}\end{array}$ & $\begin{array}{l}\text { Vinegar } \\
\mathrm{CH}_{3} \mathrm{COOH}\end{array}$ \\
\hline 1 & $\begin{array}{c}\text { Gambe / Gambir / } \\
\text { Gambier / Uncaria } \\
\text { gambir Roxb / Leaves }\end{array}$ & $\begin{array}{l}\text { 1. Mixing } 20 \mathrm{~g} \text { gambier extracts in } 2 \mathrm{~L} \\
\text { of hot water, } \\
\text { 2. Wet the sinasa leaves and boiled it } \\
\text { into the concoction for } 25 \text { minutes, } \\
\text { 3. Lift and dry the sinasa leaves in the } \\
\text { sun, } \\
\text { 4. Adding } 10 \mathrm{ml} \text { of hydrated lime } \\
\left(\mathrm{Ca}(\mathrm{OH})_{2}\right) \text { into the dye and redye the } \\
\text { leaves. }\end{array}$ & $\begin{array}{l}\text { Brown-Green / } \\
\text { PANTONE 17- } \\
1112 \text { TCX } \\
\text { Weathered Teak }\end{array}$ & \\
\hline 2 & $\begin{array}{c}\text { Ima domes } \\
\text { Root }\end{array}$ & $\begin{array}{l}\text { 1. Turmeric roots are mashed and } \\
\text { boiled in hot water in a 1:4 ratio with } \\
\text { the sinasa leaves, simultaneous ex- } \\
\text { traction and dyeing is done to } \\
\text { achieve the best result for } 15 \\
\text { minutes. } \\
\text { 2. Lift and dry the sinasa leaves in the } \\
\text { sun. } \\
\text { 3. Dyed sinasa leaves are washed and } \\
\text { immersed into } 10 \mathrm{~g} \text { hydrated lime } \\
\left(\mathrm{Ca}(\mathrm{OH})_{2}\right) \text { and } 10 \mathrm{ml} \text { vinegar } \\
\left(\mathrm{CH} \mathrm{COOH}_{3} \text {. }\right.\end{array}$ & $\begin{array}{l}\text { Brown-Yellow / } \\
\text { PANTONE 16- } \\
0946 \text { TCX } \\
\text { Honey }\end{array}$ & $\begin{array}{c}\text { Brown-Green / } \\
\text { PANTONE 17-0636 } \\
\text { TCX Green Moss }\end{array}$ \\
\hline 3 & $\begin{array}{c}\text { Fino/ Biji Buah Pinang } \\
\text { / Betel nut / Areca } \\
\text { catechu L. / Seed }\end{array}$ & $\begin{array}{l}\text { 1. Betel nuts are sliced and dried. } 20 \mathrm{~g} \\
\text { of dried betel nuts are boiled in } 4 \mathrm{~L}\end{array}$ & $\begin{array}{l}\text { Burgundy / } \\
\text { PANTONE 19- } \\
1625 \text { TCX }\end{array}$ & \\
\hline
\end{tabular}




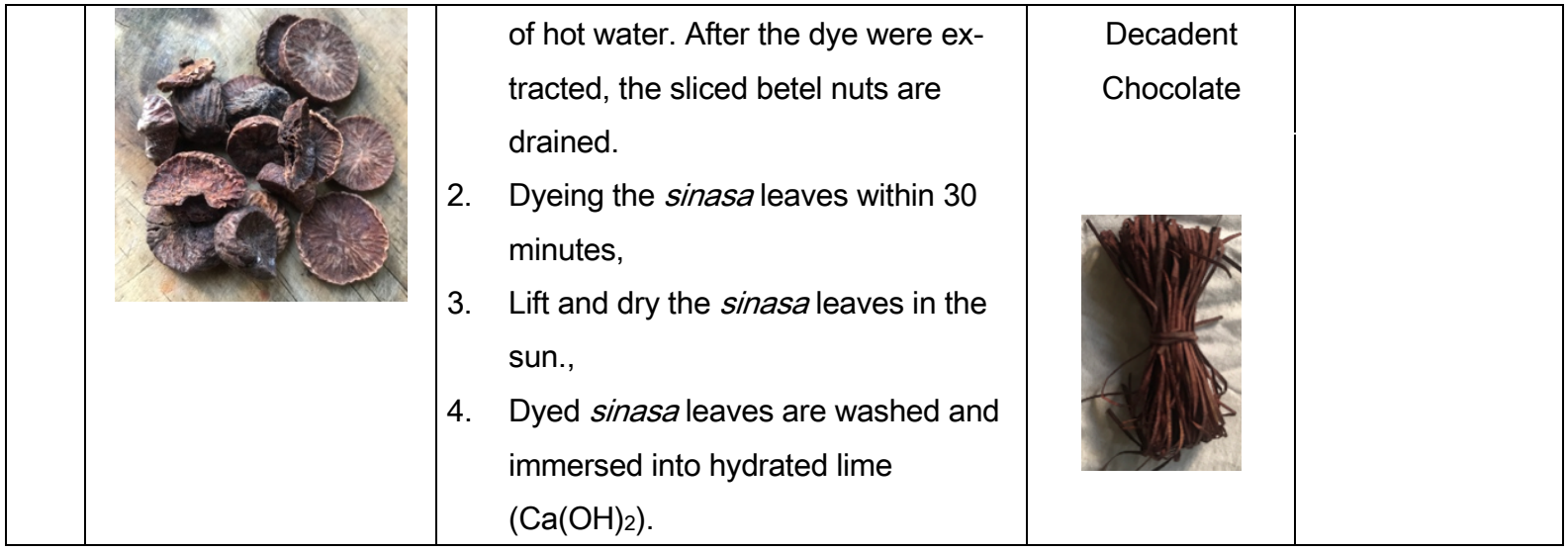

\subsection{Exploration of Nias traditional weaving decorative color composition}

The authenticity of a local souvenir are defined into: a craft's uniqueness, workmanship, aesthetics and use, cultural and historical integrity, and genuineness [12]. This paper aims to create a unique and genuine souvenir based on the aesthetic of cultural and historical integrity and created with local workmanship.
Based on Table 1, this paper uses the extracted color into the traditional weaving with the combination of several motifs with colors (Nisora). The sinasa leaves are first colored and then weaved. This paper suggested four experimented designs in refer to the Nisora weaving made by the Nias Heritage and Empowerment Foundation, Gunungsitoli, Nias. The new color composition mimics the traditional color composition for the weaver's convenience. Some of the experiments carried out are shown in Table 2.

Table 2 Exploration of Nias traditional weaving color composition and product development

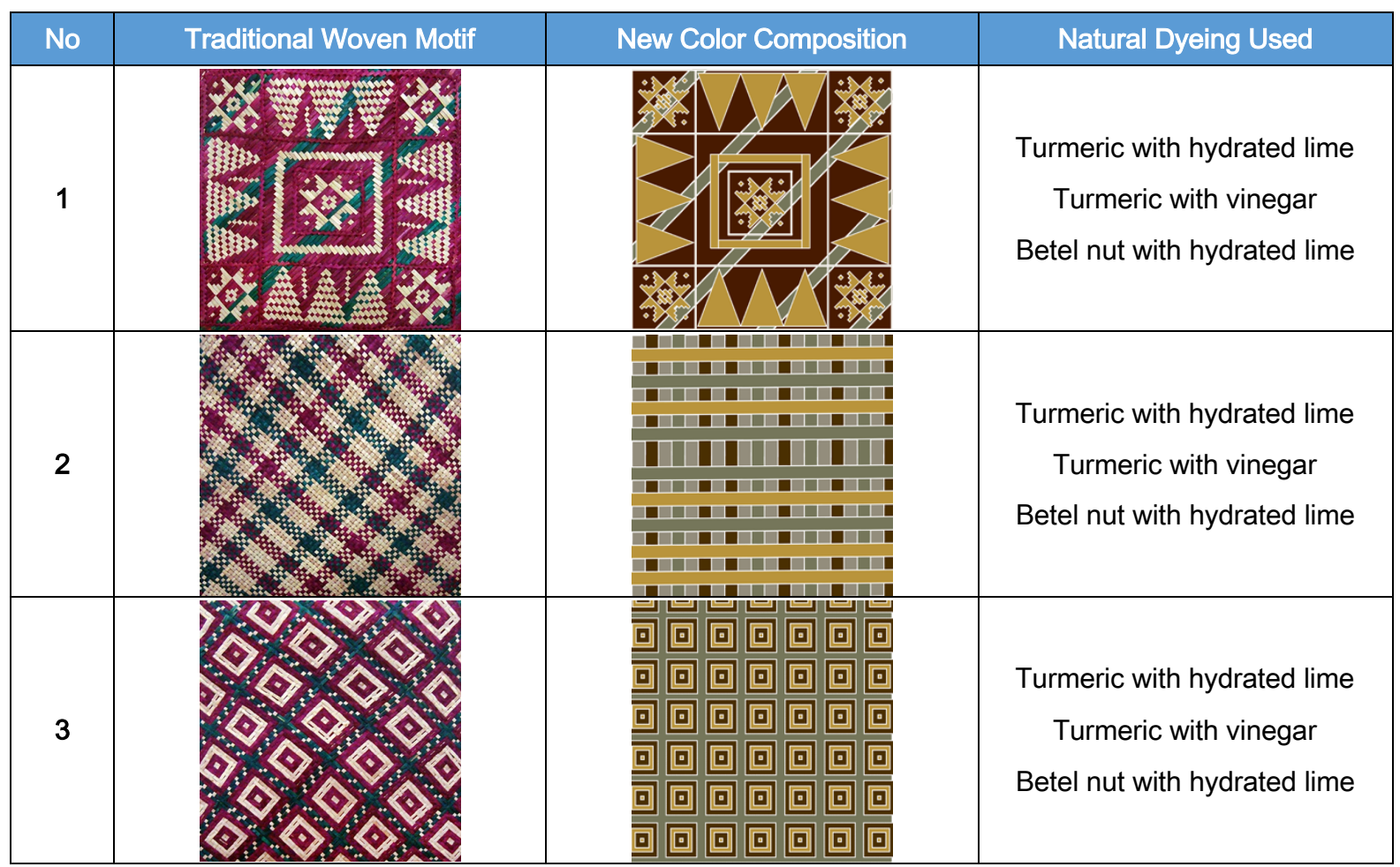




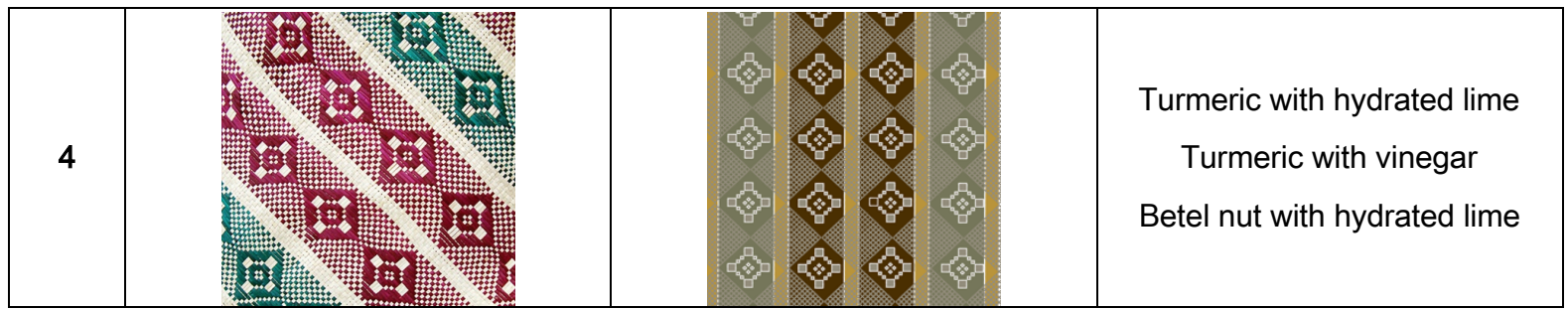

\section{CONCLUSION}

Nias traditional natural dyeing has been a forgotten technique. The usage of synthetic dye is the only knowledge known by the Nias weavers today. To create a sustainable and eco-friendly souvenir product, using natural dyes that derives from Nias nature is crucial. This ongoing research concludes that the dried sinasa leaves can be dyed with selected natural dyes and mordants. Aligned with the sustainable and natural theme, this research uses safe and available mordants for the Nias souvenir industry under the Nias Heritage and Empowerment Foundation. Gambier extract with vinegar mordant did not produce different color to the dried leaves. However, sinasa leaves dyed in turmeric extract with hydrated lime produce brownyellow color and vinegar mordant produces yellowgreen color. Last, sinasa leaves dyed in betel nut extract and hydrated lime mordant produces burgundy color. This research developed four new color decoration. Natural dyes can add value to Nias traditional weaving according to the souvenir's authenticity that is uniqueness, contain workmanship, visually aesthetics and using cultural and historical integrity, as well as genuine. For future research, more diverse natural dyes and mordants needs to be carried out continuously so that the existence Nias pandanus woven color decoration can continue to be known, in demand, and not extinct.

\section{ACKNOWLEDGMENTS}

We thank Mrs. Dina Waoma as the chairman of the Nias Heritage and Empowerment Foundation and its community for the help of identification of Nias natural dyes and the work of traditional weaving. This work was supported by Program Pengabdian Masyarakat dan Inovasi PPMI 2021 Bandung Institute of Technology.

\section{REFERENCES}

[1] Badan Pusat Statistik Kabupaten Nias Selatan, Jumlah Wisatawan (Jiwa) 2013-2015, Nias Selatan, 2016. [Online]. Available: https://niasselatankab.bps.go.id/indicator/16/48/ 1/jumlah-wisatawan.html

[2] F. (Sam) Li and C. Ryan, Souvenir shopping experiences: A case study of Chinese tourists in North Korea, Tourism Management, vol. 64, Feb. 2018, pp. 142-153, DOI: 10.1016/j.tourman.2017.08.006.

[3] J. Masset and A. Decrop, Meanings of Tourist Souvenirs: From the Holiday Experience to Everyday Life, Journal of Travel Research, vol. 60, no. 4, Apr. 2021, pp. 718-734 DOI: $10.1177 / 0047287520915284$.

[4] K. K. Swanson and D. J. Timothy, Souvenirs: Icons of meaning, commercialization and commoditization, Tourism Management, vol. 33, no. 3, Jun. 2012, pp. 489-499, DOI: 10.1016/j.tourman.2011.10.007.

[5] M. A. Littrell, L. F. Anderson, and P. J. Brown, What makes a craft souvenir authentic?, Annals of Tourism Research, vol. 20, no. 1, Jan. 1993, pp. 197-215, DOI: 10.1016/01607383(93)90118-M.

[6] J. M. Hämmerle, Asal Usul Masyarakat Nias, Yayasan Pusaka Nias, 2015.

[7] D. Waoma, Nias Traditional Weaving, Apr. 28, 2021.

[8] D. Widiawati, The Revival of the Usage of Natural Fibers and Natural Dyes in Indonesian Textile, ITB J. Vis. Art \& Des., vol. 3, no. 2, 2009, p. 14 .

[9] M. Shahid, Shahid-ul-Islam, and F. Mohammad, Recent advancements in natural dye applications: a review, Journal of Cleaner Production, vol. 53, Aug. 2013, pp. 310-331, DOI: 10.1016/j.jclepro.2013.03.031.

[10] N. Dodd, M. Cordella, O. Wolf, J. Waidløw, and M. Stibolt, Revision of the European Ecolabel and Green Public Procurement (GPP) Criteria for Textile Products, European Union, Nov. 2013. 
[11] Wahdina, D. Setiadi, P. Y, and I. Qayim, Natural dye plants used by Dayak Iban in Sungai Utik, Kapuas Hulu, West Kalimantan, Indonesia, BIODIVERSITAS, vol. 22, no. 3, Mar. 2021, pp. 1397-1404, DOI: 10.13057/biodiv/d220342.

[12] T. Irmayani, N. Nurbani, and S. Bangun, Local Genius dan Implementasi Pengarusutamaan Gender pada Pemerintahan Kabupaten di Sumatera Utara, MIMBAR, Jurnal Sosial dan Pembangunan, vol. 31, no. 2, p. 475, Dec. 2015, DOI: $10.29313 /$ mimbar.v31i2.1557.

[13] T. Telaumbanua, Kaum Milenial \& Kebudayaan Nias: Di Persimpangan Jalan, Jurnal Sundermann, vol. 1, no. 1, 2019, pp. 1-16, DOI: 10.36588/sundermann.v1i1.19.

[14] D. K. Harefa and I. Ginting, Associative Meaning Of Hendi-Hendi In Giving Afo In Nias Wedding Ceremony, The Episteme Journal of Linguistics and Literature, vol. 4, no. 3, 2018, pp. 1-24.

[15] A. B. Cunningham, I. M. Maduarta, J. Howe, W. Ingram, and S. Jansen, Hanging by a Thread: Natural Metallic Mordant Processes in Traditional Indonesian Textiles1, Econ Bot, vol. 65, no. 3, Sep. 2011, pp. 241-259, DOI: 10.1007/s12231-011-9161-4.

[16] S. Sofyan and F. Failisnur, Gambir (Uncaria gambir Roxb) Sebagai Pewarna Alam Kain Batik Sutera, Katun, dan Rayon, JLI Padang, vol. 6, no. 2, p. 89, Dec. 2016, DOI: 10.24960/jli.v6i2.1721.89-98.

[17] M. Vashishtha, Optimization of Dyeing Variables for Simultaneous Extraction and Dyeing with Pure Natural Dye Obtained from Turmeric, Journal of Basic and Applied Engineering Research, vol. 4, no. 4, p. 7, 2017.

[18] I. D. G. P. Prabawa, Ekstrak Biji BUah Pinah sebagai Pewarna Alami pada Kain Sasirangan, J. Ris. Ind. Has. Hutan, vol. 7, no. 2, p. 31, Dec. 2014, DOI: 10.24111/jrihh.v7i2.1229. 